\title{
Dossiê: História e Música
}

Sófocles ${ }^{1}$, logo no início de sua tragédia mais famosa, introduz um personagem crucial para explicar as atribulações que cercam Édipo. O personagem é Tirésias, um velho adivinho (e figura recorrente na mitologia grega) que chega conduzido por um menino. Interessado em descobrir o assassino do Rei Laio e salvar Tebas, Édipo interpela Tirésias sobre o que sabe a respeito. O diálogo é ríspido e logo tira a paciência de Édipo, pois Tirésias se recusa a revelar qualquer coisa. É então que Édipo usa um argumento surpreendente, acusando Tirésias de ser o articulador do crime, dada sua recusa em colaborar: "Pois bem. Não dissimularei meus pensamentos, tão grande é minha cólera. Fica sabendo que em minha opinião articulaste o crime e até o consumaste!". Depois da acusação, Tirésias "vira o jogo"; de "encurralado" pelas insinuações maldosas passa a assumir a condição de agente da "impávida verdade" e põe “na mesa" aquilo que Édipo jamais sonhara: “Pois ouve bem: és o assassino que procuras!"; e, na sequência, referindo-se ao casamento incestuoso com Jocasta: "Apenas quero declarar que, sem saber, manténs as relações mais torpes e sacrílegas com a criatura que devias venerar, alheio à sordidez de tua própria vida!".

É a partir desse fragmento da peça de Sófocles que gostaríamos de marcar a ideia que nutre o dossiê "história e música", agora apresentado ao público. Além de carregar o peso da idade e suas naturais inconveniências, Tirésias é cego. Isso, entretanto, não o impede de "ver"; afinal, ele é um "vidente". Temos aqui uma situação intrigante e aparentemente paradoxal: Tirésias é um "vidente cego". O paradoxo só se desfaz se entendermos a verdade que Tirésias dispõe - e que "esclarece" as etapas da vida (e do destino) de Édipo - não como um conteúdo "visual", não como um conteúdo apreensível pela "unilateralidade do sujeito que olha". Quem não "enxerga" é Édipo, apesar de ter os olhos em pleno funcionamento. A figura tirésica questiona, assim, uma tendência alimentada na cultura ocidental de que a verdade se baseia integralmente no "olhar" e confirmada pela expressão: "só acredito, vendo!". A presença de um "vidente cego" no interior da obra de Sófocles, como portador da verdade e onde se deposita a esperança de Tebas, é um manifesto sobre as potencialidades dos meios não diretamente ligados à "lógica do olhar" como instâncias de produção e transmissão de conhecimentos. É essa alteração epistêmica que permite colocar a música como forma de conhecimento do mundo, como forma de organizar sistemas de sentido sobre a experiência humana. Assim como Tirésias, a música tem a potencialidade de "ver" e de "permitir ver", oferecendo ao ouvido, conteúdos de verdade sobre as produções históricas. É essa alteração epistêmica que inspira o presente dossiê.

Conforme a tradução de Mário da Gama Kury, publicada pela editora Jorge Zahar (1998). As citações encontram-se entre as páginas 34 e 37 do referido livro. 
Por meio do dossiê "História e Música", pretendemos também socializar pesquisas e reflexões que criticam a perpetuação dos processos canonizantes da produção dos conhecimentos de fronteira entre história e música, centrados no registro escrito como documento principal, em que se tem, na maioria das vezes, a figura do compositor como protagonista e o modelo europeu como referência. Na concepção deste trabalho, nos alinhamos com a abertura do campo documental, a partir da segunda metade do século $X X$, quando se observa a inclusão da imagem como documento, a ênfase nas perspectivas da história oral, da história cultural e da micro história. Com isso, atenta-se para a inclusão da subjetividade do olhar do pesquisador, marcado por seu lugar de fala e seus marcadores sociais, a inclusão das narrativas contra hegemônicas, pós-coloniais e contra normativas.

O presente número da revista História: Debates e Tendências está organizado em três seções: a primeira compõe o "Dossiê: História e Música". A segunda seção é dedicada a artigos livres e a terceira apresenta uma resenha. Com a intenção de guiar o leitor, passamos a uma rápida apresentação das pesquisas aqui reunidas.

Abrindo o "Dossiê: História e Música", Silvia Lazo, investiga as estruturas biológicas e culturais que constituem a dominância social, articulando conceitos e categorias da antropologia, psicologia e biologia. Salienta, com essa abordagem, a importância da interdisciplinaridade para os estudos etnomusicológicos e para as compreensões históricas da experiência musical.

Os programas de concerto como fontes relevantes para a historiografia da música, é o tema do artigo seguinte. Nele, Alan Rafael Ribeiro, analisa o posicionamento estético da instituição de promoção musical Sociedade de Cultura Artística Brasílio Itiberê (Scabi) por meio dos programas dos concertos oferecidos em Curitiba (1945-1963). Destaca-se, neste trabalho, a intenção de ampliar as possibilidades de fontes primárias nas investigações sobre história e música.

Na sequência, Fernando Lacerda Simões Duarte, investiga os paradigmas instituídos pelo motu proprio sobre a música sacra de Pio X, promulgado em 1903, e seus reflexos nas práticas de música religiosa no Brasil entre 1903 e 1963. Os resultados da pesquisa indicam a existência de controle institucional, inclusive com organismos censores, sobre tais práticas.

Fechando o dossiê, Raimundo Mijares compõe uma instigante estratégia para apresentar os elementos centrais da música tradicional venezuelana: imagina uma entrevista realizada com Eladio Mujica, concertista e compositor venezuelano. $\mathrm{O}$ autor explicita, durante a entrevista imaginária, o que constitui propriamente o "venezuelano" em termos de sons musicais, articulando aspectos históricos, culturais e geográficos.

O artigo "As convulsões europeias e os seus efeitos na América Hispânica entre 1795 e 1815" abre a seção "Artigos Livres". O autor, Rémy Herrera, propõe reflexões sobre as relações entre os eventos que ocorreram de 1795 a 1815 simultaneamente na Europa e no vasto espaço que era então a América Hispânica. 
Discutir a construção da espacialidade na escrita da história dos povos tradicionais, tendo como fonte textos e representações pictóricos produzidos no âmbito acadêmico, é o objetivo do artigo seguinte. Nele, os autores José Adilçon Campigoto e Ancelmo Schörner, propõem que o croqui, o perfil esquemático e os textos acadêmicos analisados, mesmo no interior das rígidas normas da produção científica, conseguem apresentar a realidade modificada frente aos discursos e aos processos de modernização agrícola.

O próximo artigo é dedicado à história dos movimentos sociais ligados à luta pela terra, na Fronteira Sul, entre 1960 e 1980. Humberto José da Rocha examina tais movimentos utilizando referenciais teóricos que englobam além do próprio conceito de "movimento social", os conceitos de "modelo de mobilização", "repertórios", "quadros interpretativos" (frames) e "oportunização política".

Encerrando a seção "Artigos Livres", José Edimar De Souza e Luciane S. S. Grazziotin pesquisam as narrativas de "memorização" na escola normal de Porto Alegre (1882). A intenção do trabalho é reconstruir práticas pedagógicas do cotidiano da referida escola, a partir de "sabatinas" aplicadas ao alunos e que se encontram no acervo documenta do Arquivo Histórico do Rio Grande do Sul

O presente volume conta ainda com a resenha do trabalho "A crista é a parte mais superficial da onda: mediações culturais na MPB (1968-1982)" de Luísa Quarti Lamarão, elaborada pelo professor Diósnio Machado Neto. A obra de Lamarão é apresentada como imprescindível para compreender os elementos transdisciplinares que compõe a música popular brasileira nos anos de ditadura militar.

Por fim, cabe registrar o vínculo do presente número da Revista História: Debates e Tendências, de modo especial do "Dossiê: História e Música", com o Núcleo de Estudos de Memória e Cultura (Nemec), ligado ao Programa de Pós-Graduação em História da Universidade de Passo Fundo. Desejamos que a publicação fomente inspiração e debate!

Prof. Dr. Gerson Luís Trombetta, Universidade de Passo Fundo, Brasil Profa. Dra. Isabel Porto Nogueira, Universidade Federal do Rio Grande do Sul, Brasil 